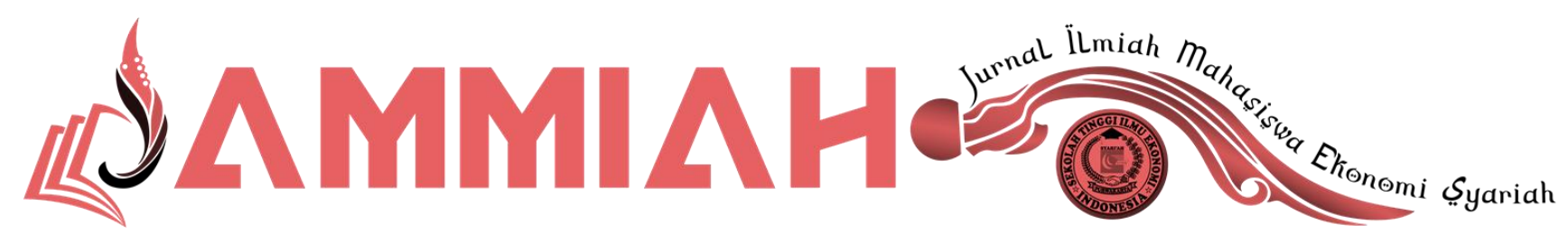

Volume 1 Nomor 2, September 2021

\title{
Prosedur Pembiayaan Kepemilikan Kendaraan Bermobil iB Di PT. Bank BRI Syariah KC Purwakarta
}

\author{
Muhamad Ramdani Zaelani ${ }^{1}$, Riski Siti Nurjanah ${ }^{2}$ \\ Sekolah Tinggi Ilmu Ekonomi Syriah (STIES) Indonesia Purwakarta \\ ${ }^{1}$ mramdanjaelani25@gmail.com \\ ${ }^{2}$ riskisitinurjanah@gmail.com
}

\begin{abstract}
ABSTRAK
Perbankan merupakan Bank yang menggunakan prinsip syariah dalam menjalankan kegiatan usahanyan dimana landasan hukum dijaalankan prinsip syariah mengacu kepada Al-Qur'an dan Hadist. Tujuan Penelitian ini di untuk mengetahui Prosedur Pembiayaan KKB iB di Bank BRI Syariah KC Purwakarta. Penelitian ini juga mengkaji terkait persetujuan pembiayaan kredit terhadap nasabah, pindah alih kepemilikan (Take over) pada Bank BRI Syariah KC Purwakarta. Termasuk juga strategi mengenai metode yang dilakukan untuk pemberian pembiayaan kredit kepada nasabah. Penelitian ini menggunakan metode penelitian kualitatif deskriptif dengan proses teknik pengumpulan data yang digunakan adalah obsevasi, wawancara, dokumentasi di lapangan.
\end{abstract}

Kata Kunci : Pembiayaan, Persetujuan, Take Over

\section{ABSTRACT}

Banking is a bank that uses sharia principles in carrying out its business activities where the legal basis is carried out by sharia principles referring to the Qur'an and Hadith. The purpose of this study was to determine the iB KKB Financing Procedure at Bank BRI Syariah KC Purwakarta. This study also examines the approval of credit financing to customers, transfer of ownership (Take over) at Bank BRI Syariah KC Purwakarta. This includes strategies regarding the methods used to provide credit financing to customers. This study uses 
descriptive qualitative research methods with the process of data collection techniques used are observations, interviews, documentation in the field.

Keywords : Financing, Approval, Take Over

\section{PENDAHULUAN}

Perbankan merupakan badan usaha yang menghimpun dana dari masyarakat dalam bentuk simpanan dan menyalurkannya kepada masyarakat dalam bentuk kredit dan atau bentuk-bentuk lainnya dalam rangka meningkatkn taraf hidup rakyat banyak. Salah satu bentuk fasilitas bank adalah munculnya perbankan syari'ah yang menyediakan produk-produk yang di perlukan oleh masyarakat dengan prinsip syari'ah. Dan bank syari'ah pun di harapkan dapat digunakan sebagai salah satu alternative perantara penyaluran dana masyarakat dengan berbagai keunggulan yang dimiliki dan fasilitas pembiayan yang berlandaskan syari'ah.

Produk perbankan syari'ah memiliki bermacam-macam, sesuai dengan keputusan bank tersebut dan bisa bersaing secara kompetitif dengan bank syari'ah lainnya. Disini perbankan syari'ah juga menawarkan berbagai jasa pembiayaan seperti simpanan mudharabah, wadiah, tabungan haji, jasa pembiayaan seperti murobahah, musyarakah, giro, umroh deposit bahkan saat beberapa perbankan juga telah menawarkan jasa pembiayaan dengan cara gadai. Dalam bentuk pembiayaan atau kredit. Perbankan syari'ah masih menerapkan produk bank konvensional tetapi disesuaikan dengan prinsip syari'ah seperti kepemilikan rumah, kepemilikan kendaraan (KKB iB) khusus diberikan kepada karyawan. ${ }^{1}$

Penelitian tentang prosedur KKB iB sudah banyak dilakukan oleh peneliti sebelumnya seperti yang dilakukan oleh Sabri Nurdin, Rafiqoh Rafiqoh, Diana Indriyani Lasabuda ${ }^{2}$ Penelitian ini bertujuan untuk mengetahui perbandingan pemberian kredit secara konvensional pada Bank BRI Konvensional Samarinda dan pembiayaan murabahah syariah pada Bank BRI Syariah Samarinda. Hasil penelitian menunjukkan bahwa analisis perbandingan sistem dan prosedur pemberian kredit pada Bank BRI Konvensional dan Bank BRI Syariah Samarinda menunjukkan bahwa terdapat dua perbedaan yang pertama fungsi Customer Service di Bank BRI Konvensional dan yang kedua bila dana nasabah telah cair pihak Account Officer akan mendampingi nasabah untuk membeli barang pada Bank BRI Syariah.

${ }^{1}$ Rudi Yasman and Afriyeni Afriyeni, "Prosedur Pemberian Kredit Pada PT. Bank Pekreditan Rakyat (BPR) Jorong Kampung Tangah (Jkt) Pariaman Cabang Padang," Jurnal Eksis, no. 7 (2019): 1-9.

${ }^{2}$ Diana Indriani Labuda Sabri Nurdin, Rafiqoh, "Analisis Perbandingan Sistem Dan Prosedur Pemberian Kredit Bank BRI Konvensional Dan Pembiayaan Murobahah Pada Bank BRI Syariah Samarinda," Jurnal Eksis 16, no. 1 (2020): 1-15.

JAMMIAH (Jurnal Ilmiah Mahasiswa Ekonomi Syariah), Volume 1, Nomor 2, September 2021 
Penelitian ini juga hanya mengkaji tentang prosedur KKB iB di Bank BRISyriah KC Purwakarta.

Penelitian-penelitian sebelumnya banyak mengkaji atau meneliti tentang kepemilikan kendaraan bermotor saja tidak dengan kendaraan-kendaraan lainnya seperti mobil, baik bekas maupun baru, dan kendaraan yang pindah alih kepemilikan (take over). Penelitian ini mengkaji lebih dalam tekait prosedur kepemilikan kendaraan bermobil baik bekas ataupun baru dan pindah alih kepemilikan (take over) KKB iB di Bank BRI Syariah KC Purwakarta termasuk strategi pemasaran yang dilakukan marketing dari Bank BRI Syariah agar pembiayaan ini banyak diminati.

Tujuan dari penelitian ini adalah untuk mengetahui prosedur pembiayaan kepemilikan kendaraan bermobil IB di PT. Bank BRI Syari'ah KC Purwakarta.

\section{TINJAUAN PUSTAKA}

\section{A. Pembiayaan Murabahah}

\section{Pengertian}

Bai al-Murabahah adalah jual beli barang pada harga asal dengan tambahan keuntungan yang disepakati. Dalam Bai Al-Murabahah penjual harus memberitahu harga produk yang ia beli dan menentukan tingkat keuntungan sebagai tambahannya. Misalnya, pedagang eceran membeli computer dari grosir dengan harga $\mathrm{Rp}$ 10.000.000,00, kemudian ia menambahkan keuntungan sebesar $\operatorname{Rp} 750.000,00$ dan ia menjual kepada si pembeli dengan harga Rp 10.750.000,00. Pada umumnya, si pedagang eceran tidak akan memesan dari grosir sebelum ada pesanan dari nasabah.

\section{Landasan syari'ah}

a. Landasan Al-Quran

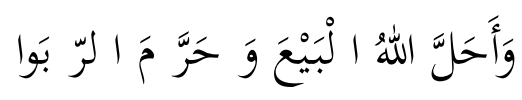

"Allah telah menghalalkan jual beli dan mengharamkan riba" (al-Baqarah :275)

b. Al-Hadist

Al-Hadist dari Suhaib ar-Rumi ra. bahwa Rasulullah SAW bersabda, "Tiga hal yang didalamnya terdapat keberkahan: jual beli secara tangguh, mugaradhah (mudharabah), dan mencampur gandum dengan tepung untuk keperluan rumah tangga bukan untuk dijual." (HR. Ibnu Majah)

\section{Rukun Murabahah}

Murabahah memiliki 5 rukun yang biasa dilakukan seperti:
a. Penjual
b. Pembeli
c. Objek/ Barang yang diperjualbelikan

JAMMIAH (Jurnal Ilmiah Mahasiswa Ekonomi Syariah), Volume 1, Nomor 2, September 2021 http://journal.sties-purwakarta.ac.id/index.php/jammiah/ ISSN: 2797-040X (Media Online) 2797-197X (Media Cetak) 
d. Uang sebagai timbangan atas objek yang diperjualbelikan

e. Sighat atau ijab dan qobul antara penjual dan pembeli.

\section{Syarat BaI al-Murabahah ${ }^{3}$}

Syarat akad murabahah adalah sebagai berikut:

a. Syarat yang berakad (baitu dan mustari) cakap hukum dan tidak dalam keadaan terpaksa

b. Barang yang diperjualbelikan (maba) tidak termasuk barang yang haram dan jenis maupun jumlahnya jelas

c. Harga barang (tsaman) harus dinyatakan secara trasparan (harga pokok dan komponen keuntungan) dan cara pembayaran disebutkan dengan jelas

d. Pernyataan serah terima (ijab qobul) harus jelas dengan menyebutkan secara spesifik pihak-pihak yang berakad.

\section{Manfaat BaI al-Murabahah}

Sesuai dengan sifat bisnis (tijaroh), transaksi baI al-murabahah memiliki beberapa manfaat, demikian juga risiko yang harus diantisipasi. BaI murabahah memberikan banyak manfaat kepada bank syari'ah maupun lembaga keuangan syari'ah lainnya. Diantaranya:

a. Adanya keuntungan yang muncul dari selisih harga beli dari penjual dengan harga jual kepada nasabah.

b. Sistem bai murabahah juga sangat sederhana, hal tersebut memudahkan penanganan administrasinya di bank syari'ah

\section{Resiko Murabahah}

Selain murabahah memiliki manfaat atau keuntungan yang dijelaskan sebelumnya, akad murabahah juga terdapat beberapa resiko yang harus di antisipasi oleh pihak lembaga keuangan syari'ah, diantaranya resiko yang ditimbulkan adalah sebagai berikut:

a. Defaul atau kelalaian : nasabah sengaja tidak membayar angsuran

b. Fluktasi harga komparatif. Ini terjadi bila harga suatu barang dipasar naik setelah bank membelikannya untuk nasabah. ${ }^{4}$ Bank tidak bisa mengubah harga jual beli tersebut

${ }^{3}$ Ernanda Kusuma Dewi and Ayu Astari, "Peran Pembiayaan Mudharabah Dalam Pengembangan Kinerja Usaha Mikro Pada BMT (Baitul Maal Wat Tamwil)," Law and justice 2, no. 2 (2018): 113.

4 Ahmad Ifham Sholihin, Buku Pintar Ekonomi Syariah (Bandung: Gramedia Pustaka Utama, 2013$), 64$.

JAMMIAH (Jurnal Ilmiah Mahasiswa Ekonomi Syariah), Volume 1, Nomor 2, September 2021 
c. Penolakan nasabah : barang yang dikirim bisa saja ditolak oleh nasabah karena berbagai sebab. Bisa jadi karena rusak dalam perjalanan sehingga nasabah tidak mau menerimanya. Karena itu, sebaiknya dilindungi dengan asuransi. Kemungkinan lain karena nasabah merasa spesifikasi barang tersebut berbeda dengan yang ia pesan. Bila bank telah menandatangani kontrak pembelian dengan penjualnya, barang tersebut menjadi milik bank. Dengan demikian bank mempunyai resiko untuk menjual kepada pihak lain.

d. Di jual. Karena bai murabahah bersifat jual beli dengan utang, maka ketika kontrak ditandatangani, barang tersebut menjadi milik nasabah. Nasabah bebas melakukan apa pun terhadap aset miliknya tersebut, termasuk untuk menjualnya.

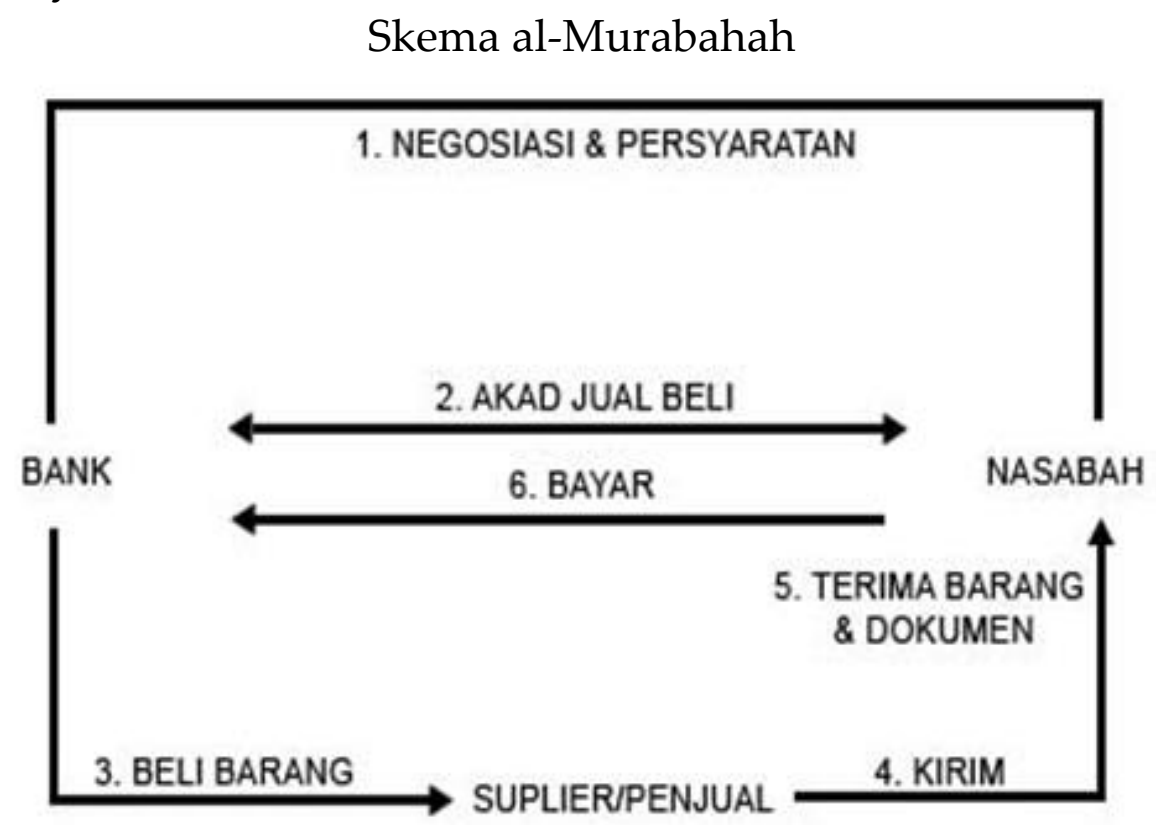

Bagan 2.3 skema al-Murabahah ${ }^{5}$

\section{B. Perbandingan Penelitian Terdahulu}

Penelitian tentang prosedur KKB iB sudah banyak dilakukan oleh peneliti sebelumnya seperti yang dilakukan oleh Juliana ${ }^{6}$ Bank Syariah juga menyediakan layanan take over sebagai solusi bagi pelanggan dalam mentransfer hutang dari Bank Konvensional ke Bank Syariah. Tujuan dari penelitian ini adalah untuk menentukan implementasi take over dan untuk mengetahui mengapa pelanggan tertarik untuk mengambil alih dari Bank Konvensional ke Perbankan Syariah di Kota Lhokseumawe.

${ }^{5}$ Moh Mufid and others, Filsafat Huku Ekonomi Syariah: Kajian Ontologi, Epistemologi, Dan Aksiologi AkadAkad Muamalah Kontemporer (DKI Jakarta: Prenada Media, 2021), 83.

6 Juliana, "Take Over Ke Bank Syariah ( Studi Kasus Pada Perbankan Syariah Di Kota Lhokseumawe )," Jurnal Kajian Ekonomi Islam 1, no. 1 (2019): 29-50.

JAMMIAH (Jurnal Ilmiah Mahasiswa Ekonomi Syariah), Volume 1, Nomor 2, September 2021 
Alasan pelanggan beralih ke bank Syariah di Kota Lhokseumawe adalah karena pelanggan menginginkan pembiayaan berdasarkan sistem syariah, mudah diakses oleh publik, prosesnya cepat, biaya administrasi dan asuransi lebih murah, sehingga pelanggan tertarik untuk beralih ke Perbankan Syariah di Kota Lhokseumawe dengan kontrak pembiayaan murabahah. Penelitian ini juga hanya menkaji tentang pemindah alihan kepemilikan (take over). Hasil penelitian menunjukkan bahwa sangat berpengaruh bagi masyarakat yang menginginkan pemindah alihan kepemilikan ini karena pelanggan menginginkan pembiayaan berdasarkan sistem syariah, mudah diakses oleh publik, prosesnya cepat, biaya administrasi dan asuransi lebih murah, sehingga pelanggan tertarik untuk beralih ke Perbankan Syariah di Kota Lhokseumawe dengan kontrak pembiayaan murabahah. Perbedaan penelitian sebelumnya dan penelitian saat ini adalah t untuk menentukan implementasi take over dan untuk mengetahui nasabah mengapa beralih ke bank syari'ah sedangkan peleintian saat ini meneliti prosedur Kepemilikan Kendaraan Bermobil Ib Bank BRI Syari'ah.

Selanjutnya penelitian dilakukan oleh Mohd Winario, Irawati, Hasgimianti, Emilia Susanti ${ }^{7}$ Hasil penelitian ini dapat disimpulkan bahwa penerapan pembiayaan murabahah BRI Syariah Pekanbaru menggunakan sistem persentase berjenjang dari tiap tahunnya dari pokok pembiayaan murabahahnya. Penentuan margin masih memperhitungkan berdasarkan BI Rate dan melihat margin yang berlaku di Bank lain. Sistem pelaksanaan pembiayaan murabahah pada bank bisa mulai dari syarat administrasi, syarat jaminan, syarat pembiayaan, plafond pembiayaan, jangka waktu pembiayaan, dan biaya yang dibebankan kepada nasabah. Dalam penetapan margin pembiayaan murabahah masih menggunakan tingkat inflasi per-tahunnya. Semakin tinggi BI rate, maka semakin tinggi pula margin yang diambil oleh bank dari nasabahnya. Perbedaan penelitian sebelumnya dan penelitian saat ini adalah penentuan margin pada setiap tahunnya berdasarkan BI Rate, sedangkan penelitian saaat ini meneliti prosedur kepemilikan kendaraan bermobil.

Selanjutnya penelitian dilakukan oleh Ulfah Khoirunisa, Asep Arifin ${ }^{8}$ Hasil penelitian dapat disimpulkan menganalisis solusi yang diterapkan oleh Bank BRI Syariah KCP Cianjur dilakukan dengan dengan tahapan prefentif dan kuratif, Proses yang menjadi penyebab terjadinya pembiayaan macet di Bank BRI Syariah KCP Cianjur disebabkan oleh faktor debitur dan kreditur, dari faktor debitur dilihat dari karakter debitur itu sendiri, dimana setiap debitur memiliki karakter yang berbeda.

\footnotetext{
${ }^{7}$ Emilia Susanti Moh Winario, Irawati, Hasgimianti, “Analisis Penerapan Pembiayaan Akad Murobahah Bank BRI Syariah (BRI Syariah) Pekanbaru," Journal of Chemical Information and Modeling 3, no. 9 (2020): 16-38.

${ }^{8}$ Ulfah Khoirunisa, "Penanggulangan Kredit Macet Pada Pembiayaan Murobahah Di Bank BRI Syariah KCP. Cianjur," Hukum Ekonomi Syariah 5, no. 2 (2018): 73-75.
}

JAMMIAH (Jurnal Ilmiah Mahasiswa Ekonomi Syariah), Volume 1, Nomor 2, September 2021 
Dari faktor kreditur dilihat dari keputusan petugas kreditur dalam memberikan pinjaman kepada debitur masih longgar dalam pemilihan data. Perbedaan penelitian sebelumnya dan penelitian saat ini adalah menganalisis solusi yang diterapkan oleh Bank BRI Syariah KCP Cianjur sedangkan penelitian saat ini meneliti prosedur pembiayaan kepemilikan kendaraan bermobil Ib di bank BRI Syariah KC Purwakarta.

\section{HASIL DAN PEMBAHASAN}

\section{A. Prosedur Pembiayaan Kepemilikan Kendaraan Bermobil iB di Bank BRI Syariah KC Purwakarta}

Pembiayaan Kepemilikan Mobil dari BRI Syriah kepada nasabah perorangan untuk memenuhi kebutuhan akan kendaraan dengan menggunakan prinsip jual beli (Murobahah), dimana pembayarannya secara angsuran dengan jumlah angsuran yang telah ditetapkan di muka dan dibayar setiap bulannya. ${ }^{9}$

Mekanisme Pemberian KKB iB dengan akad murabahah ditunjukan untuk mengetahui bagaimana prosesnya. berikut adalah proses pemberian pembiayaan KKB iB BRI Syariah KC Purwakarta 10

a. Nasabah Pengajuan Pembiayaan KKB iB

Pada tahap ini nasabah mengajukan permohonan pembiayaan KKB iB BRI Syariah, dalam pengajuan pembiayaan terebut nasabah mendatangi bank BRISyariah dan bertemu dengan pihak Account Officer (Acounting officer) untuk menanyakan informasi langsung terkait pembiayaan tersebut, diimbangi dengan pihak Account Officer yang memberikan referensi brosur dan daftar dealer yang nantinya akan membeli mobil baru/bekas untuk bekerjasama. ${ }^{11}$

b. AO menerima berkas

Tahap selanjutnya adalah pihak Account Officer menerima berkas dan dokumen yang diberkan oleh nasabah sebagai berkas pengajuan permohonan Pembiyaan KKB iB BRISyariah. Berkas-berkas yang diperlukan untuk dikumpulkan sesuai yang disebutkan pada persyaratan dan ketentuan sebelumnya.

c. AO Meneliti Kelengkapan Berkas

Selanjutnya pihak Account Officer sudah menerima berkas pengajuan pembiayaan KKB iB berupa formulir pengajuan dan formulir pendukung

${ }^{9}$ PT. Bank BRI Syariah Tbk, “KKB IB BRI Syariah,” Brisyariah.Co.Id.

${ }^{10}$ Moh Winario, Irawati, Hasgimianti, "Analisis Penerapan Pembiayaan Akad Murobahah Bank BRI Syariah (BRI Syariah) Pekanbaru."

${ }^{11}$ Sukma, Dicky Taufik. Tinjauan Analisa Pembiayaan Griya Ib Hasanah Dalam Tahapan Unit Consumer Processing Pada Pt X Syariah Kantor Cabang Bandung. Jurnal Ekonomi Bisnis, 2020, 3.1: 45-50

JAMMIAH (Jurnal Ilmiah Mahasiswa Ekonomi Syariah), Volume 1, Nomor 2, September 2021 
yang diberikan dan sudah dijelaskan pada tabel sebelumnya, petugas Account Officer wjib meneliti kembali atas kelengkapan berkas dan dokumen yang telah diberikan oleh nasabah berdasarkan persyaratan yang ada dalam check list dokumen yang biasanya ditempelkan pada bagian depan map pengajuan permohonan pembiayaan.

d. Berkas Diproses Pada Sistem SLIK/BI Checking

Selanjutnya adalah berkas yang sudah dilengkapi oleh calon nasabah pembiayaan ini akan diproses dan dilakukan pengecekan peforma nasabah dengan mengetahui riwayat pembiayaan dan pembayaran yang pernah dilakukan oleh calon nasabah tersebut. ${ }^{12}$

e. Wawancara

Setelah Account Officer menerima berkas lengkap yang sudah diperiksa melalui SLIK pihak Account Officer harus langsung melakukan wawancara. Dalam proses wawancara nsabah dapat dilakukan dengan 2 cara yang petama yaitu wawancara sebelum dilakukannya proses SIK yaitu pada saat nasabah diawal ke bank untuk mengumpulkan berkas pengajuan pihak bank dapat langsung melakukan wawancara, yang kedua setelah data SLIK didapatkan pihak Account Officer dapat melakukan wawancara yang berpedoman pada data sistem informasi debitur yang sudah dilakukan. Setelah wawancara hasil yang didapatkan harus dipindahkan pada formulir hasil wawancara.

f. Berkas Diinput Sistem Appel (Aplikasi Penunjang Pembiayaan Elektronik) Setelah Account Officer melakukan wawancara berkas akan segera diinput kedalam sistem apple. Sistem itu sendiri adalah aplikasi suatu sistem pembiayaan dan database yang sangat berguna untuk melakukan pencatan keseluruhan data pembiayaan. ${ }^{13}$

g. Validasi data

Setelah berkas data diinput sistem apple lalu Account Officer akan melakukan validasi pengecekan data apakah data tersedia tentang calon debitur adalah benar. ${ }^{14}$

h. Analisis Pembiayaan Oleh AO

Kemudian berks pembiayaan KKB iB akan dianalisis oleh Account Officer kegiatan yang dilakukan adalah menilai aspek kualitatif dan kuantitatif

12 Sukma, Dicky Taufik. Tinjauan Analisa Pembiayaan Griya Ib Hasanah Dalam Tahapan Unit Consumer Processing Pada Pt X Syariah Kantor Cabang Bandung, 2020, 3.1: 45-50

${ }^{13}$ Delvina, Aulia. Penggunaan Tanda Tangan Elektronik dalam Pengajuan Pembiayaan berdasarkan Prinsip Syariah. Jurnal Akuntansi Bisnis dan Ekonomi, 2019, 5.1: 1305-1318.

${ }^{14}$ Syaifullah, M. Djazim. Validasi data TRMM terhadap data curah hujan aktual di tiga DAS di Indonesia. Jurnal Meteorologi dan Geofisika, 2014, 15.2: 90-100

JAMMIAH (Jurnal Ilmiah Mahasiswa Ekonomi Syariah), Volume 1, Nomor 2, September 2021 
terhadap layak atau tidaknya pembiayaan tersebut dibiayai. Penilaian ini dapat diukur dengan 5C yang digunakan untuk menganalisis pengajuan pembiayaan yang terdiri dari ${ }^{15}$

1. Character

Pada penilaian ini analisis yang dilihat dari sifat, watak dan karakter kepribadian dari calon nasabah tujuannya agar mengetahui apakah keinginan untuk mengajukan pembiayaan dapat memenuhi kewajibannya untuk membayar pinjaman tersebut sampai lunas. Reputasi dari nasabah disini juga masuk dalam penilaian apakah selalu menepati janjinya, jujur dan mempunyai komitmen untuk tidak membuat permasalahan.

2. Capacity

Mengetahui kemampuan dalam membayar kewajiban calon nasabah seharusnya dibayarkan sesuai dengan jangka waktu yang sudah ditentukan

3. Capital

Penilaian disini dilihat dari kekayaan yang dimiliki oleh calon nasabah yang akan mengajukan pembiayaan, bank harus meneliti terlebih dahulu mengenai modal yang dimiliki oleh calon nasabah, semakin tinggi modal yang dimiliki oleh calon nasabah maka semakin meyakinkan pihak bank untuk memberikan pembiayaan kepada nasabah tersebut.

4. Condition

Pengetahuan kondisi eksternal seperti peta makro ekonomi (Inflasi dan perkembangan ekonomi) penelitian terhadap daerah pemasaran usaha, faktor persaingan serta strategi atau sistem pemasaran calon nasabah. ${ }^{16}$

5. Collateral

Jaminan yang diberikan oleh calon nasabah baik fisik maupun nonfisik untuk pembiayaan yang diajukan. Anggunan ini digunakan sebagai pembayaran kedua, artinya jika calon nasabah tidak dapat memenuhi kewajban angsurannya dan tergolong kedalam pembiayaan macet maka bnk dapat langsung mengeksekusi jaminan nasabah.

i. AO mengirim Appraisal

Setelah berkas sudah selesai dianalisa oleh Account Officer mengirim berkas untuk dilaksanakan appraisal biasanya mengirimkan memo. ${ }^{17}$

${ }^{15}$ Nur, Halimah. Analisis Penilaian Karakteristik Nasabah Dalam Pembiayaan Cicil Emas Di Bank Syariah Mandiri Area Cirebon, 2017, 5.1: 201-211

16 Tamara, Angelica. Implementasi analisis SWOT dalam strategi pemasaran produk mandiri tabungan bisnis. Jurnal Riset Bisnis dan Manajemen, 2016, 4.3: 100-120

${ }^{17}$ Syaifullah, M. Djazim. Jurnal Meteorologi dan Geofisika, 2014, 15.2: 90-100

JAMMIAH (Jurnal Ilmiah Mahasiswa Ekonomi Syariah), Volume 1, Nomor 2, September 2021 
j. Marketing BRIS Menilai Anggunan Yang akan Dibeli Nasabah

Setelah selesai pihak Account Officer melakukan appraisal anggunan dari yang dijaminkan dengan dinilai adalah harga pasaran ${ }^{18}$

Selanjtunya fitur yang di tawarkan dari Kepemilikan Kendaraan Bermobil di BRI Syariah adalah :

a. Plafon Pembiayaan

1. Minimal Rp. 50.000.000,-

2. Maksimal Rp. 1.000.000.000,-

b. Uang muka ringan, mulai $30 \%$

c. Bank Finance (Pembiayaan Bank)

1. Pembelian Mobil

Baru, Maksimum $80 \%$ harga on the road yang dikeluarkan dealer

Bekas, Maksimum 70\% dari nilai pasar (yang ditetapkan penilai jaminan bank)

2. Take Over Pembiayaan Kepemilikan Kendaraan Bermobil

$100 \%$ dari Outstanding lembaga pembiayaan lain atau 70\% dari nilai pasar yang ditetapkan penilai jaminan bank (mana yang terendah)

d. Jangka waktu pembiayaan Kepemilikan Kendaraan Bermobil

1. Pembelian mobil baru :

Minimal 1 tahun

Maksimal 5 tahun

Selanjutnya manfaat yang didapatkan dari Kepemilikan Kendaraan Bermobil BRI Syariah adalah :

1. Pembelian Mobil Baru

a. Top Brand

Top Brand yaitu :

1) Merk/brand yang dianggap sebagai pemimpin di industry mobil dan mempunyai demend/permintaan yang tinggi.

2) Mempunyai nilai jual kembali tinggi.

3) Mempunyai kualitas yang tinggi dan layanan purna jual yang baik.

Merk atau Brand yang termasuk kriteria Top Band adalah Toyota, Honda,

Daihatsu, Suzuki, Nissan, Isuzu, dan Mercedes Benz.

b. Non Top Brand

Non Top Brand yaitu merk/brand yang dianggap dibawah Top Brand.

2. Pembelian Mobil Bekas / Second

${ }^{18}$ Nur, Halimah. Analisis Penilaian Karakteristik Nasabah Dalam Pembiayaan Cicil Emas Di Bank Syariah Mandiri Area Cirebon. Jurnal Eksis, 2017, 5.1: 201-211

JAMMIAH (Jurnal Ilmiah Mahasiswa Ekonomi Syariah), Volume 1, Nomor 2, September 2021 
a. Termasuk mobil kategori Top Brand.

b. Tahun pembuatan terbatas dengan ketentuan jangka waktu maksimum 8 tahun dari bulan penerbitan BPKB.

c. Penjualan mobil bekas dapat berasal dari approved showroom/perorangan.

d. Wajib dilakukan pemeriksaan keaslian BPKB ke Polda setempat dan dimintakan bukti pemeriksaan keaslian tersebut.

3. Pembelian mobil CBU

4. Take Over/ pengalihan pembiayaan KKB dari lembaga pembiayaan lain.

Selanjutnya adalah persyaratan yang harus dipenuhi untuk pembiayaan ini adalah sebagai berikut :

1. WNI (Warga Negara Indonesia).

2. Pegawai/karyawan tetap dengan masa kerja atau total masa kerja ditempat sebelumnya minimal 2 (dua) tahun dari perusahaan/institusi yang memiliki reputasi yang baik, serta memiliki penghasilan tetap.

3. Professional terbatas hanya untuk profesi kesehatan (dokter, dokter spesialis dan bidan).

4. Usia minimal pada saat pembiayaan diberikan adalah 21 tahun dan pada saat jatuh tempo pembiayaan untuk karyawan adalah maksimum usia pension, 65 tahun profesi dokter/dokter spesialis.

5. Hasil track record BI Checking dan DHBI lancer/clear.

6. Tersedia Aplikasi Permohonan Pembiayaan (APP) dari calon nasabah yang telah ditandatangani oleh (calon) nasabah.

7. Membuka rekening tabungan di Bank BRI Syariah.

8. Untuk total pembiayaan minimal Rp. 50 juta Rupiah wajib menyerahkan NPWP pribadi.

\section{KESIMPULAN}

Prosedur pembiayaan KKB iB yang dilakukan oleh Bank BRI Syariah adalah calon nasabah yang diterima pembiayaan yang diajukan ya oleh pihak Account Officer, berkas-berkas yang telah dikumpulkan diteliti kembali, berkas masuk sistem SLIK, dilakukan wawancara, berkas diinput dalam sistem apple, kemudian divalidasi, masuk ke analisa pembiayaan, dalam proses pembiayaan ada fitur yang di tawarkan seperti halnya plafon pembiayaan, uang muka ringan dan bank finance. Lalu di appraisal oleh Account Officer, perhitungan anggunan, Account Officer menganalisis kembali, jika setuju Account Officer akan order notaris untuk melakukan akad setelah 
itu pencairan dan nasabah akan langsung mengangsur bulan depannya sampai jatuh tempo sesuai akad pembiayaan sampai lunas setelah itu dokumen akan dikembalikan.

\section{v. DAFTAR PUSTAKA}

Dewi, Ernanda Kusuma, and Ayu Astari. "Peran Pembiayaan Mudharabah Dalam Pengembangan Kinerja Usaha Mikro Pada BMT (Baitul Maal Wat Tamwil)." Law and justice 2, no. 2 (2018): 113.

Juliana. “Take Over Ke Bank Syariah ( Studi Kasus Pada Perbankan Syariah Di Kota Lhokseumawe )." Jurnal Kajian Ekonomi Islam 1, no. 1 (2019): 29-50.

Khoirunisa, Ulfah. "Penanggulangan Kredit Macet Pada Pembiayaan Murobahah Di Bank BRI Syariah KCP. Cianjur." Hukum Ekonomi Syariah 5, no. 2 (2018): 73-75.

Moh Winario, Irawati, Hasgimianti, Emilia Susanti. "Analisis Penerapan Pembiayaan Akad Murobahah Bank BRI Syariah (BRI Syariah) Pekanbaru." Journal of Chemical Information and Modeling 3, no. 9 (2020): 16-38.

Mufid, Moh, and others. Filsafat Huku Ekonomi Syariah: Kajian Ontologi, Epistemologi, Dan Aksiologi Akad-Akad Muamalah Kontemporer. DKI Jakarta: Prenada Media, 2021.

PT. Bank BRI Syariah Tbk. “KKB IB BRI Syariah.” Brisyariah.Co.Id.

Sabri Nurdin, Rafiqoh, Diana Indriani Labuda. “Analisis Perbandingan Sistem Dan Prosedur Pemberian Kredit Bank BRI Konvensional Dan Pembiayaan Murobahah Pada Bank BRI Syariah Samarinda." Jurnal Eksis 16, no. 1 (2020): 1-15.

Sholihin, Ahmad Ifham. Buku Pintar Ekonomi Syariah. Jakarta: Gramedia Pustaka Utama, 2013.

Yasman, Rudi, and Afriyeni Afriyeni. "Prosedur Pemberian Kredit Pada PT. Bank Pekreditan Rakyat (BPR) Jorong Kampung Tangah (Jkt) Pariaman Cabang Padang." Jurnal Eksis, no. 7 (2019): 1-9. 